\section{Publicity and priority}

SIR - The Imperial Cancer Research Fund (ICRF) is a charity dependent solely on the goodwill of the public that sustains us and devoted wholly to the cause of research aimed at preventing and curing cancer. We therefore have a responsibility to tell the public what we are doing and what are our achievements in order that they may appreciate the value of the trust they put in us and continue to support us until our mission is eventually accomplished. One important way of reaching the public is to report, through the normal vehicle of a press release and subsequent interviews, significant new results published in the scientific press, as we did for the work of $\mathrm{Dr}$ Waterfield and his colleagues on the relationship between the platelet-derived growth factor (PDGF) and the sis oncogene. It was my responsibility as director of research to suggest that this work should be the subject of a press release, which I did before I knew of the impending publication of the parallel and independent study in the United States, and to approve the final form of the statement made to the press.

Our reason for bringing forward this release was not, as you say (Nature 14 July, p.108), because we ". . . feared [we] would gain no credit for Waterfield's prior discovery", since we do not believe, as you seem to, that scientific priorities can be established by articles in the daily press. We were specifically asked by BBC Radio to make a public statement about $\mathrm{Dr}$ Waterfield's work. Had the story broken in this way to the exclusion of all other media, our news would not have had the impact that work of this importance merits, nor would we have been fulfilling our duty to the public who support us to keep them properly informed. Those of us who sometimes have the responsibility of dealing with the general news media have to be aware that a press release cannot be a long balanced technical statement giving due reference to all the many individuals usually involved in major discoveries that are always built on the work of others. Scientific accuracy must be blended with simplicity, exciting possibilities for the future must be tempered by cautious optimism and not exaggerated promises. All this we did with the utmost caution coupled with extensive further explanation in informal and formal interviews.

Arguments about scientific priority, especially in such cases as this which involve truly independent work arriving at the same discovery, are sterile and disruptive. Simultaneous independent observations only serve to strengthen the validity of the result and emphasize the teamwork and worldwide interplay of scientific activity, such as the exchange of Dr Doolittle's data base, that contribute so fruitfully to current research achievement.
We have long had a policy of providing general resources in a wide range of areas for our scientific work and, in this case, for example, the results of Dr Waterfield and his colleagues depended on a wellestablished policy of accumulating large DNA and protein sequence data bases and the resources for their analysis as developed by Peter Stockwell, Chris Rawlings and others here at ICRF, a policy established and implemented well before May this year. We emphasize the value of interaction and stimulation between our various scientific groups and, again here, Dr Waterfield and his colleagues derived stimulus from the work of Dr Rozengurt and his colleagues at ICRF on PDGF and other similar growth factors. To explain all of this and the complete background to the work would take more than even your distinguished scientific journal would accept, let alone could be compressed into a short press release.

I sincerely hope that your news item together with your republishing an extract from the News of the World does not represent a retreat from your long-established tradition as a major scientific journal, to a policy of publishing science as it might be in the general news media. Otherwise we should lose the benefit of your pages for proper presentation of scientific results where they belong, an activity not to be confused with their presentation to the general public.

WALTER F. BODMER

Imperial Cancer Research Fund, Lincoln's Inn Fields, London WC2, UK

\section{Election recount}

SIR - If most Cambridge dons do not understand their own system of single transferable votes (Nature 16 June, p.568), it is clearly not suitable for ordinary electorates.

There is one system that is fairer than first-past-the-post without either being incomprehensible or leading automatically to coalitions or breaking the link between representative and constituency. This is the two-stage election as practised in France under the Fifth Republic. In the first round, only candidates receiving more than half the vote are elected. Elsewhere there is a play-off between the two leading contenders. Supporters of disappointed candidates are thus able to express their second preference and all voters can adjust their choice in the light of the results of the first round.

It is interesting to speculate on what would have been the result of applying this system in our recent British election: 318 candidates, including 234 Conservatives and 70 Labour, would have been elected in the first round. Thus just over half the constituencies showed a clear preference. In the second round, Alliance candidates would have faced a Conservative in 57 seats, a Labour candidate in $\mathbf{2 8}$ and a minor party in 4. It seems fair to assume that the Alliance would have won most of these seats, being closer to whichever major party had been eliminated in the first round. Their grand total would have tended towards a maximum of 106.

In 219 of the remaining 233 play-offs, Conservative would have faced Labour. Which would have picked up most seats depends which the rest of the electorate considered least extreme. Note, however, that the Conservatives needed only 92 of these seats to win an absolute majority. Labour could not have reached a majority even by winning all of them. It is therefore clear who was the most likely winner.

It has been said that the French system is only suitable where parliament does not choose the prime minister. It looks as though in the present case it would have produced the same government, but with more visible support and with fair representation for the medium-sized parties. PHILIP J. STEWART Commonwealth Forestry Institute, Oxford, UK

\section{In the beginning . . .}

SIR - Your leading article "Embryology needs rules, not new laws" (Nature 28 April, p.735) is a striking example of informed self-deception. It claims that the view that early human embryos are alive is "misguided", and gives what it calls a logical argument to justify this. Allow me to take this logic a little further.

The argument is based on the premise that a living thing must be "potentially autonomously self-replicating", and concludes that, since an embryo is not autonomous, it is not alive (we shall, as does your writer, ignore the "potentially").

Having accepted this, let us now take the case of the newly born infant. This child cannot feed itself, it cannot move by itself, it is unable to reproduce and it is therefore, in fact, not an autonomously selfreplicating entity (again we ignore "potentially"). We have, as a logical extension of your writer's argument, to accept that this creature is not alive and that we are morally free to use it for any experiment we wish.

We could extend the argument even further to include the mentally handicapped, the physically handicapped, the old or indeed any helpless individual who cannot make his opinion known. The logic may be correct but do we not have reductio ad absurdum?

To say that the individual laboratory, not the law of the land, should be able to decide what is permitted is equivalent to saying that it should be left for me to decide whether I should be allowed to murder tny wife.

STEVEN LOVELL

Department of Physiology,

St Mary's Hospital Medical School, London W2, UK 